\title{
TOXIGENIC FUNGI IN BEANS (PHASEOLUS VULGARIS L.) CLASSES BLACK AND COLOR CULTIVATED IN THE STATE OF SANTA CATARINA, BRAZIL
}

\author{
Léa Luzia Freitas Costa; Vildes Maria Scussel* \\ Laboratório de Micotoxicologia, Departamento de Ciência e Tecnologia de Alimentos, Centro de Ciências Agrárias, \\ Universidade Federal de Santa Catarina, Florianópolis, SC, Brasil
}

Submitted: April 16, 2001; Returned to authors for corrections: July 12, 2001; Approved: June 10, 2002

\begin{abstract}
Toxigenic fungi were studied in beans (Phaseolus vulgaris L.) of Classes black and color, cultivated in different regions of the State of Santa Catarina, south region of Brazil. The mean counts of filamentous fungi were $2.8 \times 103$ and $6.7 \times 103 \mathrm{CFU} / \mathrm{g}$ for beans Classes black and color, respectively. Penicillium spp., Aspergillus spp. and Phoma spp. were the most frequent genera isolated, followed by Ryzopus spp., Alternaria spp., Helminthosporium spp., Cladosporium spp., Botrytis spp., Fusarium spp., Trichoderma spp., Curvularia spp. and Dreschelera spp. Among beans Class black, $24.6 \%$ of the Aspergillus strains produced mycotoxins: $13.1 \%$ produced aflatoxins (AFs); $11.5 \%$ produced ochratoxin A (OTA) and $28.9 \%$ of Penicillium produced citrinin (CTR). On the other hand, $22.1 \%$ of Aspergillus strains isolated from beans Class color produced mycotoxins (16.7\% produced AFs and $5.4 \%$ produced OTA), while Penicillium genera had $35.4 \%$ of CTR producing strains. The toxigenic species were A. flavus, A. parasiticus, A. ochraceus and P. citrinum Thom.
\end{abstract}

Key words: beans, Phaseolus, toxigenic fungi, aflatoxin, ochratoxin A, citrinin.

\section{INTRODUCTION}

Beans (Phaseolus vulgaris L.) originated from Latin America are grown and consumed mainly in Mexico, Central America, Peru, Equator, Bolivia and Brazil. They are cultivated in all Brazilian territory and there are three annual harvests. Brazil produces $c a$. 3.3 million tons of beans per year and most of the production comes from the South region, especially from the States of Paraná and Santa Catarina (3).

Beans cultivated in the State of Santa Catarina (SC) are mainly from the West, Mountain and South regions. However, the West region holds the highest production, with more than 120 thousand tones, which means $c a .38 \%$ of total SC production - 316 thousand tones in 1994/95 (3). It is important to emphasize that $60 \%$ of SC production is commercialized in other states of Brazil, especially, São Paulo.

Due to lack of appropriate management, agricultural products and their by-products, inclusive beans, may be exposed to high moisture and temperature during harvest and storage allowing fungi growth, leading to mycotoxin contamination (21).

The problem of food contamination with mycotoxins has led to an increasing concern of toxigenic fungi contamination, mainly Aspergillus, Penicillium and Fusarium genera. Widely spread in the Brazilian ecosystem, these fungi have been isolated from several food substrates, especially cereals, pulses and their by-products. Despite of that, there are only a few data on fungal contamination, their toxigenic potential and mycotoxins in pulses in Brazil, especially, on beans $(4,5,7,22)$.

Considering that there is a lack of information on toxigenic fungi in the Brazilian varieties of beans, especially concerning to production region and storage conditions, this study was carried out to evaluate fungi contamination and their toxigenic potential for ochratoxin A (OTA), aflatoxins (AFs) and citrinin (CTR) in beans Classes black and color, grown in different regions of the Santa Catarina State (SC).

\footnotetext{
* Corresponding author. Mailing address: Departamento de Ciência e Tecnologia de Alimentos, Centro de Ciências Agrárias, Universidade Federal de Santa Catarina, Caixa Postal 476, Florianopolis, SC, Brasil. Phone: (+5548) 334-4888. Fax: (+5548) 331-9943. E-mail: vildes@cca.ufsc.br
} 


\section{MATERIALS AND METHODS}

(a) Samples: 72 samples of beans $(1 \mathrm{~kg})$, Classes black and color (variety carioquinha) cultivated in six regions of Santa Catarina State, Brazil: Florianópolis, North, West, Mountain, South and Itajai Valley (Table 1). Fig. 1 shows the percentage of samples collected per region. The sample collection was carried out during one year (from Aug/97 to Aug/98) by the Laboratory of Classification of Vegetable Products (Companhia Integrada de Desenvolvimento Agrícola de Santa Catarina - CIDASC). Sample collection was done in farms and cooperatives, following the Ministry of Agriculture official method of sampling for grading (2).

(b) Mycotoxin standards: aflatoxins $\mathrm{B}_{1}, \mathrm{~B}_{2}, \mathrm{G}_{1}$ and $\mathrm{G}_{2}\left(\mathrm{AFB}_{1}\right.$, $\mathrm{AFB}_{2}, \mathrm{AFG}_{1}$ and $\mathrm{AFG}_{2}$ ), ochratoxin $\mathrm{A}(\mathrm{OTA})$ and citrinin (CTR), from Sigma.

(c) Equipment: universal moisture meter, Model CA 125 (Gehaka Co), thin layer chromatography (TLC) apparatus (Desaga) and UV cabinet, 245 and 365nm (Dist).

(d) Mycoflora determination: sub-samples (25g) of beans were ground and homogenized with $225 \mathrm{~mL}$ of peptone water $(0.1 \%)$, followed by decimal dilution preparation. Aliquots of $0.2 \mathrm{~mL}$ of each dilution were inoculated onto the surface of potato dextrose agar (PDA) acidified with $10 \%$ tartaric acid to reach $\mathrm{pH} 3.5+0.1$ ( 2 groups of 5 Petri plates each). After incubation $\left(5\right.$ days at $\left.25^{\circ} \mathrm{C}\right)$ the colonies of filamentous fungi and yeast were counted, isolated and identified up to genera using Samson et al. (19) methodology. Toxigenic strains of Aspergillus and Penicillium were identified up to species according to the taxonomic criteria of Raper and Fennell (17), Pitt $(15,16)$, Barnett and Hunter (1) and Klich and Pitt (13) for OTA, AFs and CTR production.

(e) Evaluation of toxigenic potencial: all strains of the isolated filamentous fungi from beans Classes black e color were tested for their ability to produce AFs, OTA and CTR in coconut agar at $\mathrm{pH} 5.0 \pm 0.1$ for CTR and $7.0 \pm 0.1$ for AFs and OTA $(10,13,15)$. After incubation $\left(6\right.$ days at $25^{\circ} \mathrm{C}$ ), the Petri dishes were exposed to ultraviolet light at $365 \mathrm{~nm}$ in a dark cabinet to check fluorescence. Next, an amount of the agar that surrounded the fungal colony (mainly areas were the fluorescence was more intense) was taken out and the fluorescent compound extracted with organic solvent (chloroform). The extract was submitted to TLC for identification and confirmation of the toxins using the solvent system:toluene:ethyl acetate:chloroform: $90 \%$ formic acid (35:25:25:10 v/v) and standards of $\mathrm{AFs}\left(\mathrm{AFB}_{1}, \mathrm{AFB}_{2}, \mathrm{AFG}_{1}\right.$ and $\left.\mathrm{AFG}_{2}\right)$, OTA and CTR $(8,9)$.

(f) Statistical analysis: the analysis of variance was applied and the results were considered significant when $\mathrm{P}<0.05$. The
Tukey test was used for analyses of variance for the two Classes (bean black and color) studied for total counts of filamentous fungi, toxigenic fungi and moisture content. The software used was Stat Soft ${ }^{\mathrm{TM}}$.

\section{RESULTS AND DISCUSSION}

\section{Total counts of fungi and yeast}

As expected, all samples of beans presented fungi and only four of them were contaminated with yeasts. Only a few samples of beans Class black presented yeast contamination and in very low amounts $\left(\max 8.7 \times 10^{2} \mathrm{UFC} / \mathrm{g}\right.$ ) and none were isolated from Class color. As shown in Table 1, the positive samples were from Dionísio Cerqueira (West region), Mafra, Canoinhas (North region) and São Ludgero (South region).

814 strains of fungi were isolated (Tables 2 and 3). The mean total counts of fungi in beans Classes black and color were rather different, being slightly lower $\left(2.8 \times 10^{3} \mathrm{UFC} / \mathrm{g}\right)$ in the first class than in the second $\left(6.7 \times 10^{3} \mathrm{UFC} / \mathrm{g}\right)$. In the first group (class black), the lowest count was $1.90 \times 10^{2}$ (North region, city of Mafra) and the highest $1.99 \times 10^{4}$ (Itajaí Valley region, city of Ituporanga). In the second group (Class color), the minimum was $1.0 \times 10^{2}$ (Valley region, city of Itajai) and the maximum $4.95 \times 10^{4}$ (South region, city of São Ludgero).

As far as the regions studied and the amount of fungi contamination are concerned, the beans Class color from South region of $\mathrm{SC}$ were the ones that presented the highest mean total count for filamentous fungi (max. $4.95 \times 10^{4} \mathrm{UFC} / \mathrm{g}$ ) followed by West region (max. $2.43 \times 10^{4} \mathrm{UFC} / \mathrm{g}$ ). The samples of the Mountain region had the lowest levels (max. $2.9 \times 10^{2} \mathrm{UFC} / \mathrm{g}$ ). On the other hand, the region that presented the highest contamination for beans Class black were Itajai Valley (Ituporanga city with $1.99 \times 10^{4}$ ) followed by West (city of Campos Novos with $7.0 \times 10^{3} \mathrm{UFC} / \mathrm{g}$ ).

It is important to emphasize that $4 \%$ and $8.5 \%$ of the beans Class black and color, respectively, presented mean total count of filamentous fungi and yeast higher than $10^{4} \mathrm{UFC} / \mathrm{g}$, which it is the maximum level allowed by ICMSF (11).

The moisture content (mc) of the beans for both Classes and the growth of filamentous fungi are shown in Table 1. A minimum of $13.8 \%$ and maximum of $20.9 \%$ of mc for samples Class black and minimum $14.0 \%$ and maximum of $22.4 \%$ for samples Class color were detected. The South region was the one that presented the highest levels of mc for both bean Classes, with averages of 17.5 and $21.0 \%$ for Class black and color, respectively. As expected, high fungi growth was observed in most of samples with high mc.

Only $20 \%$ of bean samples Class black and $24 \%$ Class color presented mc levels lower than the maximum limit allowed by the Brazilian regulation $-15 \%$ (2). Therefore, $c a 80 \%$ of the samples were above this limit, allowing fungi proliferation, which is of concern. 
Table 1. Mean of total count of filamentous fungi, yeast and moisture content in beans (Phaseolus vulgaris L.) Classes Black and Color from the State of Santa Catarina, Brasil (1997 - 1998).

\begin{tabular}{|c|c|c|c|c|c|c|}
\hline \multirow{2}{*}{ Class } & \multicolumn{2}{|c|}{ Sample collect } & \multirow{2}{*}{$\begin{array}{l}\text { Number } \\
\text { samples }\end{array}$} & Fungi $^{\mathbf{a}}$ & Yeast $^{\mathrm{a}}$ & \multirow{2}{*}{$\begin{array}{l}\mathrm{mc}^{\mathrm{d}} \\
(\%)\end{array}$} \\
\hline & Region & City & & \multicolumn{2}{|c|}{$\left(\mathrm{CFU}^{\mathrm{b}} / \mathrm{g} \times 10^{2}\right)$} & \\
\hline \multirow[t]{16}{*}{ Black } & West & Dionísio Cerqueira & 7 & 5.4 & 3.2 & 13.8 \\
\hline & & Campos Novos & 2 & 70.1 & $\mathrm{ND}^{\mathrm{c}}$ & 17.2 \\
\hline & & Aguas Frias & 1 & 9.7 & ND & 16.6 \\
\hline & North & Mafra & 2 & 1.9 & 8.7 & 14.8 \\
\hline & & Canoinhas & 1 & 6.5 & 1.2 & 19.1 \\
\hline & Mountain & S. José do Cerrito & 2 & 31.2 & ND & 17.4 \\
\hline & Itajaí Valey & Ituporanga & 1 & 199.0 & ND & 18.9 \\
\hline & & Blumenau & 1 & 7.9 & ND & 17.8 \\
\hline & & Itajaí & 1 & 12.0 & ND & 17.3 \\
\hline & & Major Gercino & 1 & 4.4 & ND & 14.5 \\
\hline & & Nova Trento & 1 & 3.2 & ND & 16.5 \\
\hline & South & Araranguá & 1 & 12.6 & ND & 16.5 \\
\hline & & São Martinho & 1 & 24.8 & ND & 17.9 \\
\hline & & São Ludgero & 2 & 26.8 & 1.1 & 20.9 \\
\hline & & Içara & 1 & 5.4 & ND & 15.9 \\
\hline & tal & & 25 & & & \\
\hline \multirow{26}{*}{ Color } & West & Xanxerê & 8 & 49.2 & ND & 14.8 \\
\hline & & Campos Novos & 4 & 76.9 & ND & 15.9 \\
\hline & & Águas Frias & 3 & 74.7 & ND & 18.4 \\
\hline & & Concórdia & 2 & 29.4 & ND & 17.5 \\
\hline & & Lebom Régis & 3 & 61.0 & ND & 22.1 \\
\hline & & Palmitos & 2 & 1.6 & ND & 17.5 \\
\hline & & São Lourenço & 2 & 82.7 & ND & 17.0 \\
\hline & & Chapecó & 2 & 8.0 & ND & 14.3 \\
\hline & & Fraiburgo & 2 & 2.8 & ND & 16.4 \\
\hline & & Maravilha & 2 & 7.1 & ND & 15.0 \\
\hline & & Campo Êre & 1 & 3.4 & ND & 16.0 \\
\hline & & Caibi & 1 & 35.8 & ND & 17.6 \\
\hline & & Cunha Porã & 1 & 10.9 & ND & 14.5 \\
\hline & & Pinhalzinho & 1 & 5.7 & ND & 21.0 \\
\hline & & Tangará & 1 & 243.0 & ND & 14.0 \\
\hline & & Joaçaba & 1 & 129.0 & ND & 14.7 \\
\hline & Mountain & Curitibanos & 1 & 1.5 & ND & 17.0 \\
\hline & & Lages & 1 & 2.9 & ND & 15.5 \\
\hline & Itajaí Valley & Pomerode & 1 & 4.4 & ND & 16.0 \\
\hline & & Blumenau & 2 & 34.8 & ND & 16.4 \\
\hline & & Itajaí & 1 & 1.0 & ND & 17.5 \\
\hline & Florianópolis $\mathrm{e}$ & São José & 1 & 16.7 & ND & 17.5 \\
\hline & South & São Lugdero & 2 & 495.0 & ND & 22.4 \\
\hline & & Içara & 1 & 23.2 & ND & 21.2 \\
\hline & & Tubarão & 1 & 272.0 & ND & 19.0 \\
\hline & tal & & 47 & & & \\
\hline
\end{tabular}

${ }^{\mathrm{a}}$ mean of samples; ${ }^{\mathrm{b}}$ colony forms units/gram; ${ }^{\mathrm{c}}$ not deleted by the methodology used; ${ }^{\mathrm{d}}$ Moisture content; ${ }^{\mathrm{e}}$ region of Florianopolis.

\section{Fungi genera versus bean Classes}

The following genera were identified: Aspergillus spp., Penicillium spp., Phoma spp., Rizopus spp., Alternaria spp., Helminthosporium spp., Cladosporium spp., Botrytis spp.,
Fusarium spp., Trichoderma spp. Curvularia spp., and Drescheslera spp. (Fig. 2). As Aspergillus spp. and Penicillium spp. are the most important storage fungi, it is worth emphasizing that 246 and 313 strains of them were found in 
Table 2. Toxigenic fungi in beans (Phaseolus vulgaris L.) Class black from different regions of the State of Santa Catarina Brazil.

\begin{tabular}{|c|c|c|c|c|c|c|c|c|c|c|c|c|c|c|}
\hline \multirow{2}{*}{\multicolumn{2}{|c|}{ Sample collection }} & \multirow{4}{*}{$\begin{array}{c}\text { Number } \\
\text { of samples }\end{array}$} & \multicolumn{9}{|c|}{ Genera } & \multirow{2}{*}{\multicolumn{3}{|c|}{ Total }} \\
\hline & & & \multicolumn{3}{|c|}{ Aspergillus } & \multicolumn{3}{|c|}{ Penicillium } & \multicolumn{3}{|c|}{ Others } & & & \\
\hline \multirow{2}{*}{ Region } & \multirow{2}{*}{ City } & & \multirow{2}{*}{$\begin{array}{l}\mathrm{N} \text { of } \\
\text { Strains }\end{array}$} & \multicolumn{2}{|c|}{ Toxigenic } & \multirow{2}{*}{$\begin{array}{l}\mathrm{N} \text { of } \\
\text { Strains }\end{array}$} & \multicolumn{2}{|c|}{ Toxigenic } & \multirow{2}{*}{$\begin{array}{l}\mathrm{N} \text { of } \\
\text { Strains }\end{array}$} & \multicolumn{2}{|c|}{ Toxigenic } & \multirow{2}{*}{$\begin{array}{l}\mathrm{N} \text { of } \\
\text { Strains }\end{array}$} & \multicolumn{2}{|c|}{ Toxigenic } \\
\hline & & & & $\mathbf{N}$ & $\%$ & & $\mathbf{N}$ & $\%$ & & $\mathbf{N}$ & $\%$ & & $\mathbf{N}$ & $\%$ \\
\hline \multirow[t]{3}{*}{ West } & Dionisio Cerqueira & 7 & 11 & 3 & 3 & 32 & 3 & 9.4 & 21 & $\mathrm{ND}^{\mathrm{a}}$ & ND & 64 & 6 & 9.4 \\
\hline & Campos Novos & 2 & 9 & 2 & 33.3 & 10 & ND & ND & 8 & ND & ND & 27 & 2 & 7.4 \\
\hline & Águas Frias & 1 & 4 & 2 & 50 & 5 & 2 & 40 & 1 & ND & ND & 10 & 4 & 40 \\
\hline \multirow[t]{2}{*}{ North } & Mafra & 2 & 3 & 2 & 67 & 10 & 5 & 50 & 2 & ND & ND & 15 & 7 & 46.7 \\
\hline & Canoinhas & 1 & 5 & 1 & 20 & 5 & 5 & 100 & ND & ND & ND & 15 & 6 & 40 \\
\hline Mountain & São José do Cerrito & 2 & 8 & 2 & 25 & 9 & 2 & 22.2 & ND & ND & ND & 24 & 4 & 16.7 \\
\hline \multirow[t]{4}{*}{ Itajaí Valley } & Ituporanga & 1 & ND & ND & ND & 5 & 1 & 20 & 10 & ND & ND & 15 & 1 & 6.7 \\
\hline & Blumenau & 1 & 5 & ND & ND & 5 & ND & ND & 5 & ND & ND & 15 & ND & ND \\
\hline & Itajaí & 1 & 5 & 1 & 20 & 5 & 1 & 20 & 5 & ND & ND & 15 & 2 & 13.3 \\
\hline & Major Gercino & 1 & 2 & ND & ND & 5 & 1 & 20 & 3 & ND & ND & 10 & 1 & 10 \\
\hline \multirow[t]{6}{*}{ South } & Araranguá & 1 & 2 & 1 & 50 & 5 & 5 & 100 & 3 & ND & ND & 10 & 6 & 60 \\
\hline & São Martinho & 1 & 2 & ND & ND & 5 & 4 & 80 & 3 & ND & ND & 10 & 4 & 40 \\
\hline & São Ludgero & 2 & ND & ND & ND & 10 & 4 & 40 & 15 & ND & ND & 25 & 4 & 16 \\
\hline & Nova Trento & 1 & 5 & 1 & 20 & 5 & 2 & 40 & ND & ND & ND & 10 & 3 & 30 \\
\hline & Içara & 1 & ND & ND & ND & 5 & ND & ND & 5 & ND & ND & 10 & ND & ND \\
\hline & Total & 25 & 61 & 15 & 24.6 & 121 & 35 & 28.9 & 93 & - & - & 275 & 50 & 18.2 \\
\hline
\end{tabular}

${ }^{\mathrm{a}}$ colony forms units/gram; ${ }^{\mathrm{b}}$ not detected by the methodology used.

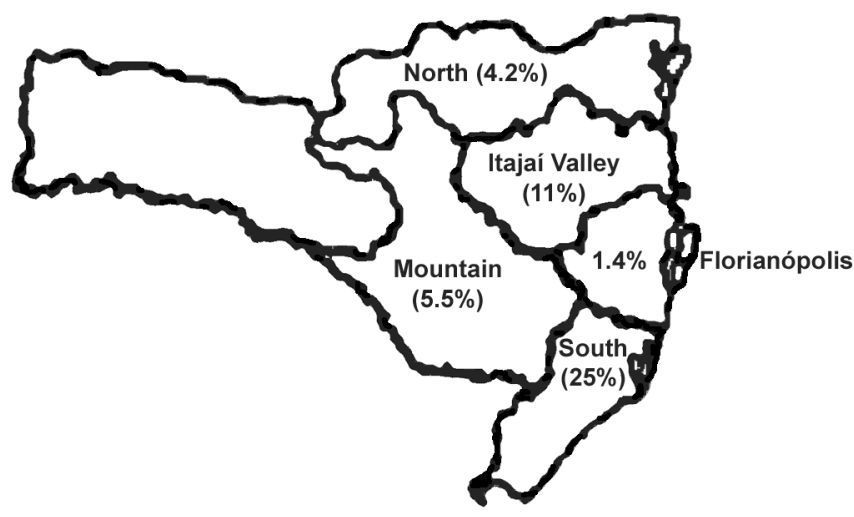

Figure 1. State of Santa Catarina, Brazil, divided in regions for bean (Phaseolus vulgaris L.) samples collection.

the beans studied, respectively (Table 4). Beans Class color presented genera Aspergillus and Penicillium almost in the same proportion ( 35.6 and $34.3 \%$, respectively). For beans Class black, the genera Penicillium presented higher values with $44.3 \%$ of the total of fungi isolated compared to only $22 \%$ for Aspergillus (Fig. 2).

These data are similar to those reported by Ruiz et al (18) in Argentine; the highest incidence was of Aspergillus spp. and Penicillium spp, with 40 and $15 \%$, respectively, for freshly harvested beans. Scussel et al. (22) studied bean samples Classes black and color, from different Brazilian states (Bahia,

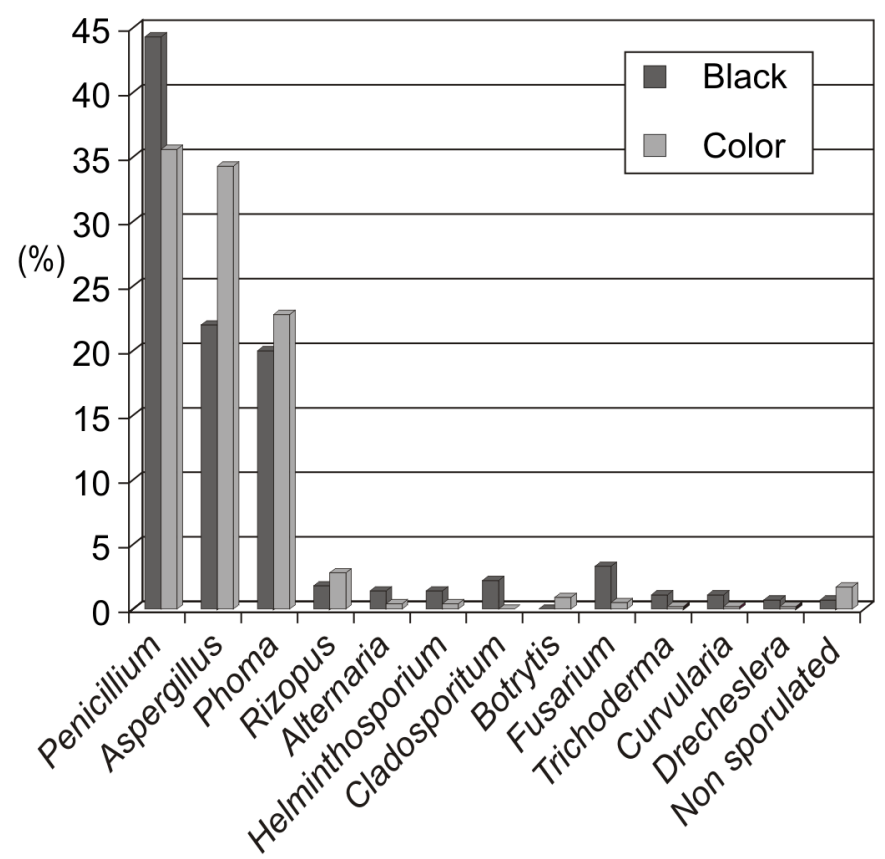

Figure 2. Fungi genera isolated from beans (Phaseolus vulgaris L.) Classes black and color collected from different regions of the State of Santa Catarina, Brazil (1997-1998).

Ceará, Minas Gerais, Mato Grosso, Mato Grosso do Sul, Paraná, and Rio Grande do Sul) and also reported the prevalence of these two genera (29.7 and $19.3 \%$, respectively). 
Apart from Aspergillus and Penicillium, other fungal genera were isolated from beans grown in Santa Catarina. A high proportion of Phoma spp. (20\%) was isolated from beans Class black, followed by smaller amounts of Fusarium spp., Cladoporium spp. and Rizopus spp. (3.3, 2.2 and 1.8\%). For all other genera (Alternaria spp., Helminthosporium spp., Trichoderma spp., Curvularia spp., and Drecheslera spp.) the percentage was lower than $1.4 \%$. In the samples of bean Class color the following genera were also isolated: a significantly high percentage of Phoma spp. (22.8\%), followed by small amounts of Rizopus spp., and Botrytis spp. (2.8 and 0.9\% respectively). Genera Fusarium spp., Alternaria spp., Helminthosporium spp., Trichoderma spp., Curvularia spp. and Drecheslera spp. were less than $0.5 \%$ of the total genera isolated (Fig. 2).

Genera Fusarium was isolated in higher proportion in beans Class black (3.2\%) than color (0.5\%). On the other hand, in the South region, the presence of Fusarium spp. was higher in beans Class black and reached $9.1 \%$ of the total of fungi isolated.
This finding is of concern, as Fusarium is considered an important field contaminant in food, that could lead to fumonisins production. In addition, the high incidence of Phoma (the third highest percentage) found in the beans studied represents a risk to the consumer as some Phoma species can produce mycotoxins - the cytochalasins (10).

The Santa Catarina regions that presented the highest incidence of fungi were (a) North, with $50 \%$ of Penicillium and $26.6 \%$ of Aspergillus, (b) West, with $46.5 \%$ of Pencillium and $23.7 \%$ of Aspergillus and (c) South, with $45.4 \%$ of Penicillium and only $7.2 \%$ of Aspergillus. The South region presented a high incidence of Phoma and Fusarium.

Toxigenic potential of isolated strains and fungi species: the fungi that presented toxigenic potential were from genera Aspergillus spp. and Penicilium spp. (Tables 2, 3 and 4).

From the total of Aspergillus strains isolated (61) from beans Class black, 24.6\% were aflatoxigenic and ochratoxigenic. From the Penicillium strains (121), 28.9\% were citrinogenic (Table 4).

Table 3. Toxigenic fungi in beans (Phaseolus vulgaris L.) Class Color ${ }^{\circ}$ from different regions of the State of Santa Catarina, Brazil.

\begin{tabular}{|c|c|c|c|c|c|c|c|c|c|c|c|c|c|c|}
\hline \multicolumn{2}{|c|}{ Sample collection } & \multirow{3}{*}{$\begin{array}{c}\text { Number of } \\
\text { samples }\end{array}$} & \multicolumn{6}{|c|}{$\begin{array}{l}\text { Genera } \\
\text { Penicillium }\end{array}$} & \multicolumn{3}{|c|}{ Others } & \multicolumn{3}{|c|}{ Total } \\
\hline \multirow{2}{*}{ Region } & \multirow{2}{*}{ City } & & \multirow{2}{*}{$\begin{array}{c}\mathrm{N} \text { of } \\
\text { Strains }\end{array}$} & \multicolumn{2}{|c|}{ Toxigenic } & \multirow{2}{*}{$\begin{array}{c}\mathrm{N} \text { of } \\
\text { Strains }\end{array}$} & \multicolumn{2}{|c|}{ Toxigenic } & \multirow{2}{*}{$\begin{array}{c}\mathrm{N} \text { of } \\
\text { Strains }\end{array}$} & \multicolumn{2}{|c|}{ Toxigenic } & \multirow{2}{*}{$\begin{array}{l}\mathrm{N} \text { of } \\
\text { Strains }\end{array}$} & \multicolumn{2}{|c|}{ Toxigenic } \\
\hline & & & & $\mathbf{N}$ & $\%$ & & $\mathbf{N}$ & $\%$ & & $\mathbf{N}$ & $\%$ & & $\mathbf{N}$ & $\%$ \\
\hline \multirow[t]{16}{*}{ West } & $\overline{\text { Xanxerê }}$ & 8 & 28 & 6 & 21.4 & 28 & 8 & 28.6 & 16 & $\mathrm{ND}^{\mathrm{a}}$ & $\mathrm{ND}$ & 72 & 14 & 19.4 \\
\hline & Campos Novos & 4 & 32 & 9 & 28.1 & 11 & 3 & 27.3 & 6 & ND & ND & 49 & 12 & 24.5 \\
\hline & Águas Frias & 3 & 7 & ND & ND & 15 & 6 & 40.0 & 12 & ND & ND & 34 & 6 & 17.6 \\
\hline & Concórdia & 2 & 2 & ND & ND & 6 & 2 & 33.3 & 7 & ND & ND & 15 & 2 & 13.3 \\
\hline & Lebom Régis & 3 & 16 & 5 & 31.3 & 11 & 4 & 36.4 & 8 & ND & ND & 35 & 9 & 25.7 \\
\hline & Palmitos & 2 & 7 & ND & ND & 10 & ND & ND & 3 & ND & ND & 25 & ND & ND \\
\hline & São Lourenço & 2 & 7 & 2 & 28.6 & 9 & 7 & 77.8 & 9 & ND & ND & 25 & 9 & 36.0 \\
\hline & Chapecó & 2 & 7 & 2 & 28.6 & 6 & ND & ND & 12 & ND & ND & 25 & 2 & 8.0 \\
\hline & Fraiburgo & 2 & 5 & 1 & 20.0 & 10 & 4 & 40.0 & 5 & ND & ND & 20 & 5 & 25.0 \\
\hline & Maravilha & 2 & 6 & 2 & 33.3 & 9 & 2 & 22.3 & 10 & ND & ND & 26 & 4 & 15.3 \\
\hline & Campo Erê & 1 & 3 & ND & ND & 5 & 2 & 40.0 & 5 & ND & ND & 10 & 2 & 20.0 \\
\hline & Caibi & 1 & 3 & ND & ND & 5 & 5 & 100 & 7 & ND & ND & 15 & 5 & 33.3 \\
\hline & Cunha Porã & 1 & 3 & ND & ND & 10 & 6 & 60.0 & 2 & ND & ND & 15 & 6 & 40.0 \\
\hline & Pinhalzinho & 1 & 8 & 3 & 37.5 & 2 & 1 & 50.0 & ND & ND & ND & 10 & 4 & 40.0 \\
\hline & Tangará & 1 & 3 & ND & ND & 5 & ND & ND & 7 & ND & ND & 15 & ND & ND \\
\hline & Joaçaba & 1 & 5 & ND & ND & 5 & ND & ND & 10 & ND & ND & 20 & ND & ND \\
\hline \multirow[t]{2}{*}{ Mountain } & Curitibanos & 1 & 10 & 3 & 30.0 & ND & ND & ND & ND & ND & ND & 10 & 3 & 30.0 \\
\hline & Lages & 1 & 2 & ND & ND & 5 & ND & ND & 3 & ND & ND & 10 & ND & ND \\
\hline \multirow[t]{3}{*}{ Itajaí Valley } & Pomerode & 1 & 5 & 2 & 40.0 & 3 & 1 & 33.4 & 2 & ND & ND & 10 & 3 & 30.0 \\
\hline & Blumenau & 2 & 5 & 1 & 20.0 & 14 & 6 & 42.9 & 4 & ND & ND & 23 & 7 & 30.4 \\
\hline & Itajaí & 1 & 4 & ND & ND & 5 & 2 & 40.0 & 2 & ND & ND & 11 & 2 & 18.9 \\
\hline Florianópolis & São José & 1 & 2 & ND & ND & 5 & 5 & 100 & 3 & ND & ND & 10 & 5 & 70.0 \\
\hline \multirow[t]{4}{*}{ South } & São Ludgero & 2 & 8 & 2 & 25.0 & 10 & 4 & 40.0 & 7 & ND & ND & 25 & 6 & 24.0 \\
\hline & Içara & 1 & 5 & 3 & 60.0 & 3 & ND & ND & 7 & ND & ND & 15 & 3 & 20.0 \\
\hline & Tubarão & 1 & 5 & ND & ND & ND & ND & ND & 15 & ND & ND & 20 & ND & ND \\
\hline & Total & 47 & 185 & 41 & 22.1 & 192 & 68 & 35.4 & 162 & - & - & 539 & 109 & 20.2 \\
\hline
\end{tabular}

${ }^{\mathrm{a}}$ colony forms units/gram; ${ }^{\mathrm{b}}$ not detected by the methodology used; ${ }^{\mathrm{c}}$ variety carioquinha. 
Table 4. Toxigenic potential of strains isolated from beans (Phaseolus vulgaris L.) Classes black and color from State of Santa Catarina, Brazil.

\begin{tabular}{|c|c|c|c|c|c|c|c|c|c|}
\hline \multirow{3}{*}{ Genera } & \multirow{3}{*}{$\begin{array}{c}\text { Number of strains } \\
\text { Class black }\end{array}$} & \multicolumn{6}{|c|}{ Toxigenic potential } & \multicolumn{2}{|c|}{ Total } \\
\hline & & \multicolumn{2}{|c|}{$\mathrm{AF}^{\mathrm{a}}$} & \multicolumn{2}{|c|}{$\mathrm{CTR}^{\mathrm{b}}$} & \multicolumn{2}{|c|}{ OTA $^{c}$} & \multirow[b]{2}{*}{$\mathbf{N}$} & \multirow[b]{2}{*}{$(\%)$} \\
\hline & & $\mathbf{N}$ & $(\%)$ & $\mathbf{N}$ & $(\%)$ & $\mathbf{N}$ & $(\%)$ & & \\
\hline Aspergillus & 61 & 8 & 13.1 & - & - & 7 & 11.1 & 15 & 24.6 \\
\hline Penicillium & 121 & - & & 35 & 28.9 & - & & 35 & 28.9 \\
\hline Other & 93 & - & - & - & - & - & - & - & \\
\hline Total & 275 & 8 & 2.9 & 35 & 12.8 & 7 & 2.5 & 50 & 18.2 \\
\hline \multicolumn{10}{|c|}{ Class color d } \\
\hline Aspergillus & 185 & 31 & 16.7 & - & - & 10 & 5.4 & 41 & 22.1 \\
\hline Penicillium & 192 & - & - & 68 & 35.4 & - & - & 68 & 35.4 \\
\hline Other & 162 & - & - & - & - & - & - & - & - \\
\hline Total & 539 & 31 & 5.8 & 68 & 12.6 & 10 & 1.0 & 109 & 20.2 \\
\hline
\end{tabular}

${ }^{\mathrm{a}}$ aflatoxins; ${ }^{\mathrm{b}}$ citrinin; ${ }^{\mathrm{c}}$ ochratoxin $\mathrm{A} ;{ }^{\mathrm{d}}$ variety carioquinha.

Beans Class color had $22.1 \%$ of the Aspergillus strains that produced AF and OTA. With a higher percentage (35.4\%) of citrinogenic Penicillium than the Class black (Table 3). Cyclopiazonic acid and fumonisin production was not evaluated. As far as toxigenic potential of the strains and the sample collection regions are concerned, no difference among them could be observed.

The fungi species identified from the bean samples contaminated with Aspergillus and Penicillium were A. flavus, $A$. parasiticus, $A$. ochraceus and $P$. citrinum Thom.

The Aspergillus species isolated from beans Class black and the types of toxins produced were as follows: $11.5 \%$ of $A$. ochraceus produced OTA; $6.5 \%$ of $A$. flavus produced only $\mathrm{AFB}_{1}$ and $3.3 \%$ produced $\mathrm{AFB}_{1}$ and $\mathrm{AFB}_{2}$. In addition, $3.3 \%$ produced the four aflatoxins $\left(\mathrm{AFB}_{1}, \mathrm{AFB}_{2}, \mathrm{AFG}_{1}\right.$ and $\left.\mathrm{AFG}_{2}\right)$. The OTA production was higher for Class black $(11.5 \%)$ than for color (5.4\%). The incidence of P. citrinum was also lower in this Class. Apart from OTA producers, $8.6 \%$ of the A. flavus strains isolated from beans Class color produced $\mathrm{AFB}_{1}$ and $\mathrm{AFB}_{2}$; and $4.8 \%$ produced only $\mathrm{AFB}_{1}$. A. parasiticus $(3.3 \%)$ produced $\mathrm{AFB}_{1}, \mathrm{AFB}_{2}, \mathrm{AFG}_{1}$ and $\mathrm{AFG}_{2}$. It was observed that $3.5 \%$ of $P$. citrinum produced citrinin.

The analysis of variance of the two Classes of bean showed that there was not a significative difference among them, either for fungi total counts, toxigenic fungi potential and $\mathrm{mc}$ of the samples.

It is important to emphasize that the detection of toxigenic fungi in food does not mean presence of mycotoxin, especially if the fungus is not exposed to conditions that allow its growth. However, presence of toxigenic fungi indicates that there are potential risks of mycotoxin contamination. When the food is a good substrate for fungi growth and mycotoxin production. When the food is exposed to physical factors such as high moisture content and temperature, the risk of contamination increases, especially during long term storage $(12,21)$.
The toxigenic tests do not give all the information due to differences on fungi behavior in different medium and/or different substrates (23). Therefore, the data obtained have to be considered only as an indicative.

The high incidence of ocratoxinogenic and citrinogenic strains in both Classes of beans is of concern, as the target organs for both toxins are the kidneys. Considering that beans are the staple food of the Brazilian population, extensive to some other Latin American countries, it is important to take into perspective that this exposure can lead to nephropathies with unknown cause. A parallel study in bean samples demonstrated that OTA contamination was much higher than $\mathrm{AFB}_{1}(6)$.

\section{ACKNOWLEDGEMENTS}

The authors acknowledge the Companhia Integrada de Desenvolvimento Agricola - CIDASC - through Mr. O. Volpato and staff of the Laboratory of Classification of Vegetable. Products of Santa Catarina State for the samples collection.

\section{RESUMO}

\section{Fungos toxigênicos em feijão (Phaseolus vulgaris L.) classes preto e cores cultivado no Estado de Santa Catarina, Brasil}

Foram estudados fungos toxigênicos em feijão (Phaseolus vulgaris L.), classes preto e cores, cultivados em diferentes regiões do Estado de Santa Catarina, região Sul do Brasil. A média total de fungos filamentosos foi de $2,8 \times 10^{3}$ e $6,7 \times 10^{3} \mathrm{UFC} /$ $\mathrm{g}$ para feijão classe preto e cores, respectivamente. Penicillium spp., Aspergillus spp. e Phoma spp. foram os gêneros mais frequentes isolados, seguidos por Ryzopus spp., Alternaria spp., Helminthosporium spp., Cladosporium spp., Botrytis spp., Fusarium spp., Trichoderma spp., Curvularia spp. e 
Dreschelera spp. No feijão classe preto, $24,6 \%$ das cepas de Aspergillus isolados eram toxigenicas: $13.1 \%$ eram produtoras de aflatoxinas (AFs) e 11,5\% de ocratoxina A (OTA); e 28,9\% de Penicillium produziram citrinina (CTR). Por outro lado, $22,1 \%$ de cepas de Aspergillus isolados do feijão classe cores, produziram micotoxinas (16,7\% produziram AF e 5,4\% produziram OTA), já do gênero Penicillium, $35,4 \%$ das cepas produziram CTR. As espécies toxigênicas isoladas foram $A$. flavus, A. parasiticus, A. ochraceus e P. citrinum Thom.

Palavras-chave: feijão, Phaseolus, fungos toxigênicos, aflatoxina, ocratoxina $\mathrm{A}$, citrinina.

\section{REFERENCES}

1. Barnett, H.L.; Hunter, B.B. Illustrated Genera of Imperfect Fungi. New York: Macmillan Publishing Company, 1986, 218p.

2. BRASIL - Ministério da Agricultura. Norma de identidade, qualidade, embalagem e apresentação do feijão. Portaria n.161, de 24 de julho 1987. Diário Oficial da República Federativa do Brasil, Brasília, p.13-14, 1 de Set. 1987.

3. CEPA - Instituto de Planejamento e Economia Agrícola de Santa Catarina - Sintese Anual da Agricultura de Santa Catarina. Florianópolis, 1999.

4. Costa, L.L.F. Levantamento de fungos toxigênicos e contaminação por micotoxinas em feijão (Phaseolus vulgaris L.) cultivado no Estado de Santa Catarina, periodo de 1997-1998. Florianópolis, 2000, 45-65p. Dissertação (Mestrado em Ciências dos Alimentos) Centro de Ciências Ágrarias. Univrsidade Federal de Santa Catarina.

5. Costa, L.L.F.; Scussel, V.M. Toxigenic fungi in beans (Phaseolus vulgaris L.). Revue de Medecine Veterinaire, p.518, 1998.

6. Costa, L.L.F.; Scussel, V.M. Micotoxinas em feijao (Phaseolus vulgaris L.) comercializado no estado de Santa Catarina. In: IX Encontro Nacional de Micotoxinas. Florianopolis, Maio de 1998, p.130.

7. Cruz, L.C.H.; Santuário, J.M.; Rosa, C.A.R.; Campos, S.G. Caracterização da microbiota toxigênica da superficie do feijão. VI Encontro Nacional de Micotoxinas. São Paulo, 1990, p.57.

8. Cruz, L.C.H.; Campos, S.G.; Rosa, C.A.R. Aplicação de agar-coco como meio diferencial para o isolamento de fungos citrinogênicos. Arq. Univ. Fed. Rur. Rio de Janeiro, 15(1): 61-64, 1992.
9. Gimeno, A. Improved method for thin layer chromatographic analysis of mycotoxins. J. Assoc. Off. Anal. Chem., 63(2): 182-186, 1980 .

10. Griffin, D.H. Fungal Physiology, $2^{\text {nd }}$ ed. New York: Wiley-Liss, 1994, $458 \mathrm{p}$.

11. ICMSF - International Commission on Microbiological Specifications for Foods. Ecologia microbiana de los alimentos. Volume 2. Cereales y sus productos derivados. Zaragoza: Editorial Acribia S.A. 1980a, p.679-738.

12. Jayas, D.S. Heat, moisture, and gas transfer in stored-grain ecosystems. In: Scussel, V.M.(ed). Atualidades em Micotoxinas e Armazenagem de Grãos, VMS, Florianópolis, 2000, p.282-289.

13. Klich, M.A.; Pitt, J.I. A Laboratory Guide to Common Aspergillus Species and their Telemorphs. North Ryde, N.S.W.: Csiro Divison of Food Processing, 1988.

14. Lin, M.T.; Dianese, C.J. A coconut-agar medium for rapid detection of aflatoxin production by Aspergillus spp. Phytopathology, 66: 1466-1469, 1976.

15. Pitt, J.I. The Genus Penicillium and its Teleomorphics States; Eupenicillium and Taloromyces. Academic Press, London, 1979, $634 \mathrm{p}$.

16. Pitt, J.I. Food mycology - an emerging discipline. J. Applied Bacteriology. Symposium Supplement. 67(18): 75-95, 1988.

17. Raper, K.B.; Fennell, D.I. The Genus Aspergillus. Baltimore. Williams \& Wilkins Company, 1965, 686p.

18. Ruiz, J.A.; Bentabol, A.; Gallego, C.; Angulo, R.; Jodral, M. Mycoflora and aflatoxin-producing strains of Aspergillus flavus in greenhousecultivated green beans (Phaseolus vulgaris L.). J. Food Prot., 59(4): 433-435, 1996

19. Samson, K.M.J.; Busta, F.F.; Petterson, E.H.; Johnson, M.G. Colony Count Methods. In: Vanderzant, C.; Splittstoesser, D.F. Compendium of Methods for the Microbiological Examination of Foods. $3^{\text {rd }}$ Ed., Washington: American Public Health Association, 1992, p.7596.

20. Scussel, V.M. Micotoxinas em Alimentos. Editora Insular, Florianópolis, 1998, 144p.

21. Scussel, V.M. Atualidades em Micotoxinas e Armazenagem de Grãos, VMS, Florianópolis, 2000, 382p.

22. Scussel, V.M.; Volpato, O.; Costa, L.L.F.; Silva, E.L.; Souza, G.D. Fungi and aflatoxin production in beans (Phaseolus vulgaris L.) from Brazil. Revue de Medicine Veterinaire, 1998. p.531.

23. Taniwaki, M.H.; Silva, N. Métodos em Micologia de Alimentos. In: Fungos Deterioradores de Alimentos Ocorrência e Deteç̧ão. Laboratorio de Microbiologia- ITAL, Campinas, São Paulo, 1996, p.37-45. 